On the Phytotoxicity of Postemergence Application of MCC [Methyl-N(3, 4-dichlorophenyl) carbamate; Swep] on Dry-seeded Rice Plants

\author{
Kunio Yamane, Hideo Chisaka* and Masao Arai* \\ Hyōgo Prefectural Agricultural Experiment Station, Akashi, Hyōgo, and ${ }^{*}$ Central \\ Agricultural Experiment Station, Konosu, Saitama
}

\begin{abstract}
Summary
Studies on the injurious effect of methyl-N-(3,4-dichlorophenyl)carbamate (swep; MCC in Japan) on rice plants were made in pot experiments under various spraying conditions.

Rice plants before or soon after emergence were tolerant to swep, but the susceptibility became greater as the growth stage advanced. By the spraying of swep at the 2.5 to 3 leaf stage rice plants were injured mostly and some were killed, while the rice seedlings having one true leaf were resulted a slight injury.

These injurious effects were greater in the manufactured formulations of 1966 than of 1965 . Seedlings grown feebly under partially shaded sun-light were more susceptible.
\end{abstract}

\title{
3,4-Dichloropropionanilide の選択殺草作用に関する研究
}

\section{第 3 報 水稲の栽培条件および生育ステージ別の DCPA 解毒分解について}

\author{
全購連農業技術センター 伊藤 堯・利根川和江・上島俊治
}

\section{1. 緒言}

イネ科属間選択除草剤である 3,4-dichloropropionanilide (DCPA, propanil) について, 筆者 ${ }^{1,2)}$ らは稲 とヒエ（稄）に対する選択殺草作用は，植物体の加水分 解酵素による DCPA の分解解毒能力と植物体への浸透 力の差によるむのであることを明らかにし，その加水分 解酵素についても種々の検討の結果を報告した。

一般に，DCPA のノビエその他雑草に対しての殺草 力は, 土鎄水分含量が低い時効果が大きく, 高い時効果 が劣ること, 雑草の 1 2 葉期に殺草力が最大でそれよ り生育が進むと効果が低下し ${ }^{4,5}$, 稲の生育が進んだ場 合薬害を受けにくくなるが, 多空素, 遮光状態で生育し た軟弱な苗(2) は薬害を受けやすいことがいわれている。

筆者らは, 水稲の DCPA による薬害の発現に関し て, 肥料条件をかえ施肥方法を改善することによつて, DCPA 加水分解酵素を増強させて薬害を軽減させ得る かぞうか，また同時に，軟弱に育つた水榣に薬害が出や
すいこと，水稲の苗代期に薬害が多く現われることおよ びヒエの生育が進むと殺草力が低下することなどの知見 が，DCPA 分解能とどのような関連をもつかを明らか にするために，栽培条件を異にした水稲および生育ステ ージ別の水稲および食用ビエにお污る DCPA 分解解毒 能の変動について, 植物体のホモジネートを用いて実験 を行なつたので，その結果を報告する。

\section{2. 実 験 方 法}

\section{(1) 試料植物とホモジネートの調製}

試料植物は水稲（農林 8 号）と食用ビエを用い温室内 で栽培した。試料植物のホモジネートの調製は前報と同 様で, 試料植物に $\mathrm{M} / 20$ リン酸カリ緩衝液およびけい砂 を加え乳鉢で磨砕し，緩衝液 $10 \mathrm{~m} l$ 当り試料植物 $1 \mathrm{~g}$ を 含むホモジネートを作り，これを遠心分離 $(2,000 \mathrm{rpm}$, 5 分間) した上清液を用いた。

\section{（2） DCPA の定量}

DCPA 純品（工業用原体を含水エタノールで再結し 
たもの，mp. 90 $91^{\circ} \mathrm{C}$ ) を前報と同㥞少量のエタノー ルに溶解後, 緩衝液で希釈し $25 \mu \mathrm{g} / \mathrm{m} l$ とし, ホモジネ 一ト $10 \mathrm{~m} l$ に DCPA 溶液 $5 \mathrm{~m} l$ を添加し $30^{\circ} \mathrm{C}$ 恒温 槽に 24 時間放置後, DCPA をベンゼン $+n$-ヘキサ ン $(1+1)$ 混液で抽出し, 溶媒を除去後残查を塩酸 (1 +1) で加水分解し，生ずる 3,4-dichloroaniline を $N$-naphthylethylendiamine とカップリングし比色す る後藤》の方法によつた。

\section{（3）試料植物の栽培条件}

水稲栽培の水耕液組成は，木村氏に準拠し第 1 表に示 すものを使用した。窒素，燐酸，加里多肥区をそれぞれ 標準区の 3 倍量とし，同時に窒素，燐酸，加里欠乏区を 設けた。水耕には $1 / 5,000$ a ポットを用い，水耕液は 1 週間に一度更新した。

第 1 表 水稲水耕栽培条件

\begin{tabular}{|c|c|c|c|c|c|c|c|}
\hline \multirow{2}{*}{ 区 $_{\text {肥 }}$} & \multicolumn{2}{|c|}{$\mathrm{N}$} & \multirow{2}{*}{$\mathrm{p}_{2} \mathrm{O}_{5}$} & \multirow{2}{*}{$\mathrm{K}_{2} \mathrm{O}$} & \multirow{2}{*}{$\mathrm{CaO}$} & \multirow{2}{*}{$\mathrm{MgO}$} & \multirow{2}{*}{$\mathrm{Fe}_{2} \mathrm{O}_{3}$} \\
\hline & $\mathrm{MH}_{4}-\mathrm{N}$ & $\mathrm{NO}_{3}-\mathrm{N}$ & & & & & \\
\hline 標 準 区 & 10.2 & 12.8 & 13.0 & 17.2 & 20.5 & 22.1 & 3 \\
\hline $\mathrm{N}$ 多肥区 & 10.2 & 58.8 & 13.0 & 17.2 & 20.5 & 22.1 & 3 \\
\hline $\mathrm{N}$ 欠乏区 & - & - & 13.0 & 17.2 & 20.5 & 22.1 & 3 \\
\hline$P$ 多肥区 & 10.2 & 12.8 & 39.0 & 17.2 & 20.5 & 22.1 & 3 \\
\hline P 欠乏区 & 10.2 & 12.8 & - & 17.2 & 20.5 & 22.1 & 3 \\
\hline $\mathrm{K}$ 多肥区 & 10.2 & 12.8 & 13.0 & 51.6 & 20.5 & 22.1 & 3 \\
\hline $\mathrm{K}$ 久文区 & 10.2 & 12.8 & 13.0 & - & 20.5 & 22.1 & 3 \\
\hline
\end{tabular}

注) 単位 $\mathrm{mg} / \mathrm{l}$; 使用水性水道水

さらに土耕区は，1/5,000 a ポットを用い，各ポッ 卜当り高度化成 $(14: 10: 13) 2 \mathrm{~g}$ を加光, 温室内で 10 月 1 日から 11 月 24 日まで栽培した。土耕区のうち遮光 区は，第 2 表市るように，標準区の約 $1 / 10$ 日光量と し，また乾田区は 1 週間に 1 度土表面に土割れが起きな

第 2 表 標準区扣よび遮光区の照度

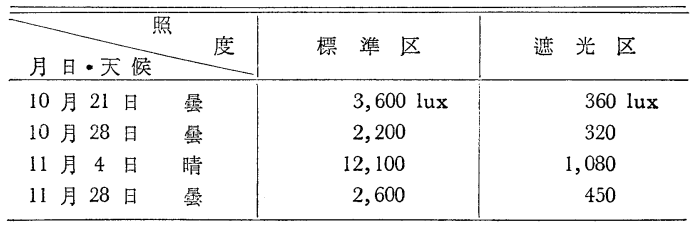

第 3 表 栽培条件による水稲の生育状態

\begin{tabular}{|c|c|c|c|}
\hline & 草丈 (cm) & 根長 $(\mathrm{cm})$ & 生育葉数 \\
\hline 標 潐 区 & $27 \pm 2$ & $13 \pm 1$ & 6 \\
\hline $\mathrm{N}$ 多肥区 & $27 \pm 3$ & $13 \pm 1$ & 6 \\
\hline $\mathrm{N}$ 欠之区 & $20 \pm 3$ & $19 \pm 7$ & 5 \\
\hline$P$ 多肥 区 & $31 \pm 3$ & $14 \pm 1$ & 6 \\
\hline$P$ 欠 之区 & $20 \pm 3$ & $24 \pm 4$ & 5 \\
\hline $\mathrm{K}$ 多肥区 & $30 \pm 4$ & $13 \pm 1$ & 6 \\
\hline $\mathrm{K}$ 欠之区 & $20 \pm 2$ & $25 \pm 2$ & 5 \\
\hline 湛 水 区 & $39 \pm 6$ & - & 6 \\
\hline 乾 田 区 & $34 \pm 4$ & - & 6 \\
\hline 遮 光 区 & $25 \pm 7$ & - & $4 \sim 5$ \\
\hline
\end{tabular}

い程度に散水管理した。

水稲とヒエの生育ステージ別 DCPA 分解能について 調べた試料は， $1 / 1,000 \mathrm{a}$ ポットの苗箱において，基肥 として $\mathrm{a}$ 当り窒素 $1.3 \mathrm{~kg}$, 燐酸 $1.0 \mathrm{~kg}$, 加里 $1.2 \mathrm{~kg}$ を加え, 本葉 8 葉期まで温室内で栽培した。栽培期間は 9 月 1 日から 12 月 26 日，ならびに 12 月 22 日から 3 月 14 日までであつた。

\section{3. 実験結果および考察}

\section{（1） 水稲の栽培条件による DCPA 分解解毒能}

栽培条件の異なる水稲体加らの各木モジネートの DCPA 分解力の変動が第 1 図に示される。

いずれの区においても葉身部ホモジネート DCPA 分 解量は葉鞘部ホモジネートのそれより高い。一方, 窒 素, 燐酸, 加里各多肥区の DCPA 分解力が標準区と比 較してとくに差があるとはいえない。各養分欠そ区の 分解力は標準区と比較してかなり低いが，肥料条件をか えることにより DCPA 分解能力を増大させ薬害を軽減 させることは難かしく，またいずれの養分が不足しても 薬害発現の危険をもつている上考えられる。

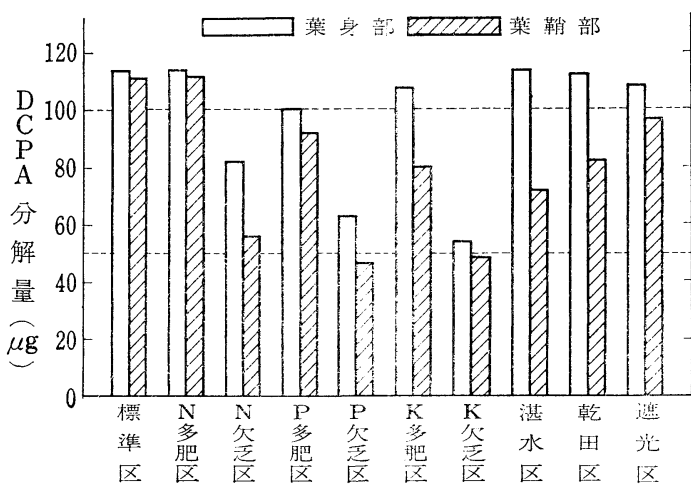

第 1 図 水稲の栽培条件汅よる DCPA 分解量

乾田状態および遮光状態で生育した水稲体ホモジネー トの DCPA 分解量を, 湛水状態で生育した水稻体ホモ ジネートの分解力と比較すると，これらの間には明らか な差は認められない。

したがつて軟弱な水稲苗に薬害が多い現象は，水稲体 内の DCPA 分解解毒能が軟弱苗において劣るのではな く, DCPA 分解解毒以外の, 浸透の差などの他の要因 によるものと考えられる。

\section{（2）各生育ステージにおける水稲および食用ビエの DCPA 分解解毒能の変化}

水稲およびヒエの葉身, 葉鞘部ホモジネートの本葉 1.5 葉期から 8 葉期までの DCPA 分解量を第 2 3 図 に示す。DCPA 添加量はい亭れも $125 \mu \mathrm{g}$ である。 


\section{i) 水稲葉身部ホモジネートの DCPA 分解力}

第 2 図から，1.5 葉期〜 2 葉期ではかなり高い分解力 を示すが, 以後漸次低下し 4 5 葉期にかけて最低とな り特徵的な谷を形成する。この時期から 1 週間後の 5 葉 期以降になると, DCPA 分解力は, 初期分解力と同等 またはそれ以上に強くなり, さらに 7 葉期以降は $3 \sim 4$ 葉期の DCPA 分解力とほぼ同等の分解力となつて安定 する。

この 4 5 葉期にかけて DCPA 分解力がかなり彽下 するのは，この時期が肧乳による自己栄養期から光合成 や肥料に依存するいわゆる離乳期にあたつているので， 体内に大きな代謝変化があるためと思われる。したがつ てこの時期に DCPA を散布した場合, 水稻の DCPA 分解解毒能の低下による薬害が起こりやすいと考えられ るので，この時期での DCPA 散布はさけるべきであろ う。実際にこの時期における DCPA 散布で水稲が薬害 を生ずることがしばしばみられる。

ii）水稲葉鞘部ホモジネートの DCPA 分解力

図より葉身部の DCPA 分解力と比較すると, 葉鞘部 のそれは弱いといえよう。2 3 葉期，4～5 葉期に分解 量が低下しているが，その他は葉身部ホモジネートの DCPA 分解量とほぼ同様である。

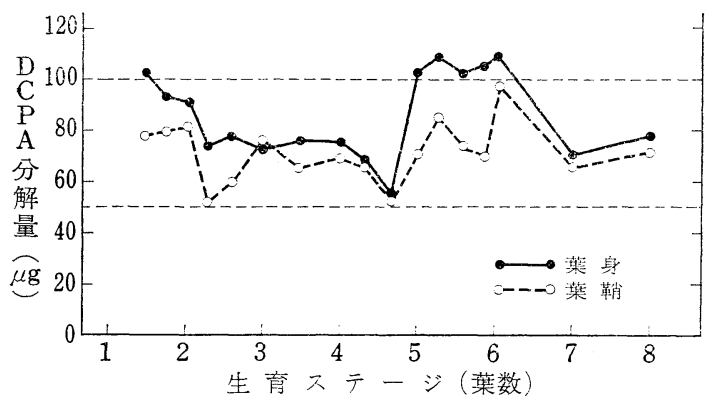

第 2 図 水稲体ホモジネートの DCPA 分解量

これらの DCPA 分解量の推移から, 従来いわれてい る苗代期散布に薬害が多く現われるのは, 苗代期におい て水稲体内で一時的に DCPA 分解力が低下することに よるものであり, 生育が進むと薬害を受けにくくなるこ とは 5 葉期以降の水稲の DCPA 分解力が再び増大する ことによるものと考えられる。

以上の実験水稲体ホモジネートをそのまま用いて行 なつたものであり, 酵素活性, 抽出効率などこれら in vitro での解毒と in viro での解毒とにおいて種々の問 題があり，これらの問題については DCPA 分解酵素の 精製によりさらに確認する必要がある。

iii）ヒエ葉身, 葉朝部ホモジネートの DCPA 分解量 食用ビエ葉身および葉䩗部のホモジネートの DCPA
分解力は, 水稲と比較して非常に弱く, また葉身・葉鞘 部間ならびに 1.5 葉期〜 8 葉期の葉期間で DCPA 分解 力に差が羿められない。

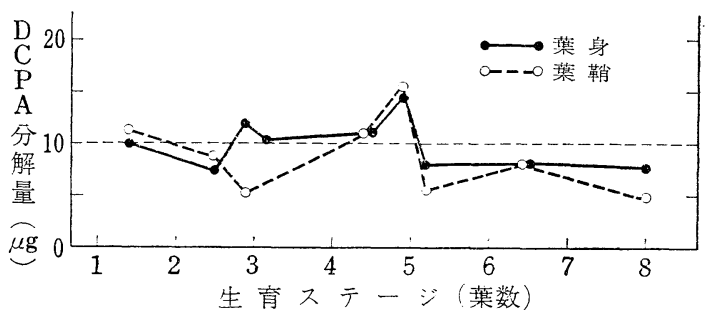

第3図ヒエ体ホモジネートの DCPA 分解量

したがつて，4〜5 葉期以上のヒエに DCPAを散布 した場合，その殺草力が低下するここは，ヒエ体内にお ける DCPA 分解解毒能が増大するためではなく, ヒ 工体内への浸透力, あるいは体内構成成分や代謝系の DCPA 感受性などに変化があるためと考えられる。

\section{4. 要約}

水稲の薬害発現に関して栽培条件をちがえた水稲, お よび生育ステージ別の水稲とヒエの DCPA 分解解毒能 について，そのホモジネートを用いて検討した。

（1）水稲を，水耕法により肥料 3 要素である窒素, 燐酸, 加里について, 多肥区および久そ区で生育させた 場合，それらの DCPA 分解能は多肥区においては標準 区と明らかな差は認められず，欠乏区においてはかなり の低下が認められた。

（2）土耕法で栽培した水稲ホモジネートの DCPA 分解力は, 湛水区・乾田区間および遮光区・対照区間で 明らかな差が認められなかつた。

（3）生育ステージ別に，1.5 葉期から 8 葉期まで水 稲およびヒエの葉身, 葉鞘部の DCPA 分解力を測定し た結果, 水稲では生育初期にかなり高い分解力を示し, 4〜5 葉期に初期分解力の約半分にまで低下し，5葉期 以降再び高い分解力を示すことがわかつた。

ヒエにおいては, 葉身, 葉䩗部とも 1.5 葉期から 8 葉 期まで DCPA 分解力にほとんど差がなく，分解力その 当のは水稲にくらべかなり低かつた。

\section{参考 文 献}

1）足立明朗・利根川和江・上島俊治：農薬生産技術 14, 19 22 (1966).

2）足立明朗・利根川和江 -上島俊治: 農藻生䧑技衍 $15,11 \sim 14$ (1966).

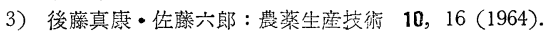

4) Sмiтн, R. J. Jr: Weed 9 (2), 318 322 (1961).

5) HUdGins, H. R : IRC News letter 11 (1), 1 6 (1962).

6) 原田哲夫・江戸議治：雑慗研究 1，96 (1961). 


\title{
Studies on the Selective Action of 3,4-Dichloropropionanilide Herbicide
}

Part 3. Propanil Detoxication in Various Conditions of Cultivation and the Growth Stages of Rice Plant and Barnyardgrass

Takashi Ito, Kazue Tonegawa and Toshiharu Ueshima

Zenkoren Agricultural Technical Center, Hiratsuka, Kanagawa

\section{Summary}

Regarding the phytotoxicity over rice plant, some experiments were carried out to investigate propanil detoxication in various conditions of cultivation and in the growth stages of rice plant and barnyardgrass by these tissue homogenates.

1. In rice plant cultivated with each excessive quantity and deficiency of nitrogenous, phosphoric and potassium fertilizers, propanil decomposing activity of the excessive quantity plot was almost equal with the standard plot, while in the deficiency decreased very much.

2. Much different was not recognized in propanil decomposing activity among the flooded, the dried and the shaded plots.

3. Propanil decomposing activity of blade and sheath of rice plant and barnyardgrass from 1.5 th leaf stage to 8th leaf stage was examined using these tissue homogenates. The homogenate of rice plant in early stages had high propanil decomposing activity and lowest during 4th-5th leaf stage, the weaning stage. After 5th leaf stage the activity was as high as in early stages.

4. In the homogenates of barnyardgrass, propanil decomposing activity was epual at each stages from 1.5 th to 8 th leaf stage and very lower than rice plant.

\section{除草効果に及ぼす DCPA と CHCH の相乗作用}

\author{
イハラ農薬研究所 近内誠登・一前宣正・高橋善郎
}

イネ科属間選択性除草剂 $\mathrm{DCPA}^{32}$ は，イネ栽培地帯 の初期雑草枯殺剤として広く実用化されている。本剤は 茎葉に処理することによつて刹草効果を発揮するもの で, 降雨, 雑草のステージ, 希釈水量等によつて殺草効 果が変動し ${ }^{1)}$ ，なかでも処理後の降雨は殺草効果に及ぼ す影響が高く，また降雨によつて処理適期怘失すること が多く，実用上問題となることが多い。

このような観点から，箨者らは，DCPA の選択性を そこなうことなく DCPA の雑草体内浸透を増し, 雨に よる影響の少ない処方および共力剤を検索した結果，ア ノン系化合物である $\mathrm{CHCH}$ (cyclohexenyl cyclohexanone) が DCPA との間に共力効果のあることが判明 した。
$\mathrm{CHCH}$ は本来有機溶媒としての性質があり，また $\mathrm{CHCH}$ 自体殺草効果を示し，イネには害が少ないとい う選択性を有するが，DCPA に比べて選択性の幅が狄 く，単剤の実用化には難がある。しかしながら DCPA とある比率で混合するとき，DCPA の選択性を失うこ となく, 高い殺草効果を示すことがみとめられた。本剤 は一般名 STI-100 と称するもので, 以下この名称を用 いて報告する。<smiles>O=C1CCCC1C1CCCCC1</smiles>

$\mathrm{CHCH}$ の 化学棈造 